\title{
The Female Labour Force Participation, a Matter of Supply? a Matter of Demand? An Exercise of Reconstruction in a Context of Poverty, Barcelona, 1930- 1950
}

\section{Introduction}

Some historical studies on women's work and family strategies during the nineteenth century and the first half of the twentieth, both internationally and in Catalonia, consider that supply-side factors determined female labour force participation. From this perspective, most of the authors conclude that married women's work basically depended on the husband's income (Saito, 1981) and, therefore, they worked mainly during the most critical periods of the family life cycle (Scott \& Tilly, 1975; Hareven, 1982; Roberts, 1982; Van Den Eeckhout, 1993; Knotter, 2004; Nicolau, 1990; Robinson, 1995; Camps 1998; Llonch 1993, 2007). Yet other research, especially in recent years, challenges this supply-side perspective and emphasises the importance of demand-side factors. In this approach, female labour force participation was determined by the local labour market structure as well as the labour opportunities available (Haines, 1979; Horrell \& Humphries 1995, 1997; Borderías, 2010, 2012, 2013; PérezFuentes \& Pareja, 2011; Muñoz, 2012a, 2012b; Humphries \& Sarasúa, 2012; Campos, 2013; Garrido-González, 2015). Labour opportunities, in turn, were conditioned by institutional and cultural factors (Haines 1979; Horrell \& Humphries 1995, 1997).

This article addresses this issue - Does women's work respond to supply or demand factors? - by analysing the labour force participation rate of a group of women who, at some point between 1930 and 1950, were employed as metallurgical workers in the city of Barcelona. This particular group of women were chosen because they belonged to the 
poorest segment of Barcelona's female working class, which has received little attention in studies devoted to women's labour force participation in Catalonia. ${ }^{1}$

The period selected for this study is a crucial period in the history of Spain and the city of Barcelona. After the industrial expansion of the 1920s that was encouraged by the dictatorship of Primo de Rivera (1923-1930), Barcelona, one of the main industrial centres in Spain, reached one million of inhabitants in 1930 due to the migratory wave that began during the First World War. However, a period of economic stagnation and social and political upheaval began, which intensified after the proclamation of the Second Republic in 1931. In 1936, General Franco's military coup sparked a three-year civil war, after which the Franco dictatorship maintained a policy of severe political and social repression. Franco also launched an autarkic economic policy that left the country mired in a deep crisis until the early 1960s. The second, and more important, reason for which this period is of particular interest is that in the context of the changes described, the reconstruction of women's rates of labour force participation based on data from the National Population Censuses (Borderías, 1993a) indicates that the labour force participation among married women, which grew during the first third of the twentieth century, fell during Francoism. ${ }^{2}$ Sociologists have linked this decline to higher fertility

\footnotetext{
${ }^{1}$ On the activity of female textile workers see: Nicolau (1990); Llonch (1993; 2007); Ferrer (1995); Camps 1998; 2002; 2004); Borderías, Villar \& González-Bagaría (2011) Borderías (2012; 2013), Borderías \& Ferrer (2015).

${ }^{2}$ According to the National Population Censuses, the rate of female labour force participation in the city of Barcelona had been rising since the beginning of the twentieth century, but stagnated between 1930 and 1970 (at roughly 30\%). More specifically, the proportion of married women in the population of working women dropped sharply (from $39.43 \%$ in 1930 to $19 \%$ in 1970) and the workforce in the industrial sector became increasingly male (the percentage of women fell from $33.24 \%$ in 1930 to $19.49 \%$ in 1975). These data may be found in Borderías (1993a, pp. 35-38 and tables 3, 6 and 9). According to data from the Sociodemographic Survey of 1991, there was also a fall in the labour force participation rates of women between 25 and 45 years of age in Spain as a whole between 1940 and the mid-70s
} 
rates and the weak tradition of employment outside the home among the immigrants who came to Barcelona in large numbers after the war (Pinilla, 1979). ${ }^{3}$ Historians, however, have argued that immigrant women had more difficulties in gaining access to the industrial labour market since they had acquired their skills at home and in their birthplaces, which were predominantly rural (Borderías, 1993b). ${ }^{4}$ The main aim of this article is to analyse how the labour behaviour of this group of poor working-class women changed over this period, and the factors that contributed to these changes.

Previous studies of female labour force participation in Barcelona have not addressed these issues, as they have focused on the first third of the twentieth century. However, all of them do concur that the continuity of women's working trajectories, once married, depended primarily on demand-side factors, such as the availability of jobs and, from the supply-side, the ability to rely on other women to carry out domestic chores (Borderías, 2002, 2003, 2004; Borderías \& López Guallar, 2003; Borderías, Villar \& González-Bagaria, 2011). Specifically, the main obstacles to female labour force participation were the intense segmentation of the labour market and the entry restrictions against women (Domènech \& Elu-Terán, 2008). During Francoism, the demand for female labour became more restricted as the continuance of married women

(Miret, Alustiza \& Cámara, 2001). The decrease in the participation rates of married women in the labour force during the twentieth century until the mid-seventies also occurred in other southern European countries like Italy and Greece. In contrast, northern Europe - in such places as Sweden, the Netherlands, and the United Kingdom - and also the United States experienced significant increases in the labour force participation of married women from 1960 (Costa, 2000).

${ }^{3}$ See the data in Pinilla (1979, appendix no. 7, tables 189 and 190, pp. 559-560).

${ }^{4}$ Other studies find that immigrant women have traditionally occupied the lower strata of the Catalan occupational structure: they have been less common in industry, specifically in the textile sector, and more so in lower value-added areas of the tertiary sector, such as in domestic service (Solé, 1981; Llonch, 1994; López Guallar, 2004). In 1930, 65.64\% of the women who worked as domestic servants in the city of Barcelona were non-Catalan immigrants (Borrell, 2016: 79). 
in the labour market complicated the situation even further. The impact of the severe and long industrial recession after the civil war was especially hard on the textile sector, in which female labour force participation was traditionally very high (Borderías, 1993a). Demand also declined in other industrial sectors due to the discriminatory labour legislation against married women - such as the reimposition of the "marriage bars" in many jobs. ${ }^{5}$ More precisely, the possible changes in the female workforce demand in the metalworking sector after the civil war and the role played by the labour regulations implemented by the state will be discussed.

It should also be taken into account that, as pointed out in the case of other areas of Spain, the discriminatory social and labour legislation under Franco influenced families' labour strategies. Thus, the family subsidies policy discouraged married women from working outside of the home (Babiano, 2005), especially among women who worked in lower-paid sectors and had limited opportunities to pursue a career (Fernández Gómez, 2000). However, even when the discriminatory labour legislation blocked their working trajectories in the regular labour market, in the context of a dramatic deterioration in living conditions, ${ }^{6}$ married women swelled the ranks of the informal labour market (Pérez-Fuentes, 2003; Vilar, 2006; Pérez Pérez, 2007). ${ }^{7}$ Therefore, this article analyses the work of this group of women within the framework of the family, paying particular attention to factors such as their origin and educational level, which determined individuals' opportunities in the labour market.

\footnotetext{
${ }^{5}$ The marriage bar was not adopted in the Catalan textile industry.

${ }^{6}$ After the civil war, the Spanish working class lost $50 \%$ of its purchasing power and in 1950 per capita income was still 15\% lower than in 1929 (Vilar, 2006: 22-29).

${ }^{7}$ For more on the discriminatory legislation against women under Franco, see Scanlon (1976); Telo (1986); Ruiz Franco (2003, 2007). For the consequences of applying the marriage bar in the case of the telecommunications company Telefónica, see Borderías (1993a).
} 
The article is divided into three parts. The first sets out very briefly the sociodemographic features of the women in the study. The second deals with the sources - the social security contribution records (1921-2004) and Barcelona's municipal censuses (1930-1950) - as well as the methodology - nominative record linkage - used to bring to light the women's remunerated activities, the calculation of underreporting and the reconstruction of the women's labour participation rate by age. The link between the evolution of this rate and the hiring policies for the female workforce in the metallurgical industry will be examined. The last part focuses on the relationship between women's employment and the family life cycle by measuring the impact of marriage, reproductive burden and household type on their working lives.

\section{The group of working women in the study: socio-demographic characteristics}

In total, the labour force participation of 431 women, born between 1867 and 1956, is included in this study. At some point in their working lives, they were all employed in the metallurgical sector. More specifically, they all had jobs at Hijos de Gerardo Bertrán (HGB), a manufacturer of tin-plate cans and boxes with a long history (18621978). The firm was highly representative of the new manufacturers of small metallic objects that began cropping up in the last quarter of the nineteenth century in Sant Martí de Provençals, which was Barcelona's leading industrial district until the 1970s. HGB was located in an area straddling the neighbourhoods of El Poblenou (in the Sant Martí de Provençals district) and La Barceloneta (in the Ciutat Vella district), and the firm employed women who mostly lived in these two neighbourhoods, which had historically been areas with a high concentration of non-Catalan immigrants from other regions of Spain, particularly from Murcia and Andalusia (Alabart, 1982, p.63; Tatjer, 
1980; Oyón, Maldonado \& Griful, 2001). Unsurprisingly, therefore, the working women in this study were mostly of immigrant origin - only around $40 \%$ were born in Barcelona (Table 1) and most of them were second-generation immigrants - having arrived in Barcelona with their parents when they were very young. In general, as already mentioned, they belonged to working-class families of low social status $78.16 \%$ were daughters of unskilled labourers with a high level of illiteracy $(41 \%)$ - and marriage to immigrants of similar standing $-70 \%$ of their husbands were also unskilled labourers - did not lead to higher social status.

\section{[Table 1 near here]}

Indeed, this proletarian profile became more pronounced among the families of the women born from the mid-twenties onwards. The generation born between the late nineteenth century and the mid-twenties of the twentieth, reflecting the migration flows to Barcelona at that time, came from other parts of Catalonia, as well as Valencia and Aragon - the communities bordering Catalonia (Table 1) -. Both natives and immigrants had a high level of literacy $(50-70 \%)^{8}$, and the reproductive rates of the latter were fairly similar to those of the Catalan population: the women workers born prior to 1915 had, on average, 2.97 children, which lay between the number of offspring in Catalonia (from 2.86 to 1.89 ) and in Spain (from 4.04 to 2.88) among the generations born between 1886 and 1915 . Their social integration in the city was favoured by the fact that they lived in the central areas of El Poblenou and La Barceloneta, both of which were areas characterised until the 1930s as working-class melting pots with craftsmen, day labourers and, to a lesser extent, small traders and groups of white collar

\footnotetext{
${ }^{8}$ In comparison to the $43 \%$ female literacy rate in the city of Barcelona in the early twentieth century (according to data from the National Population Census of 1900).
} 
workers (Oyón, 2008). In contrast, the women workers born later, from the second half of the 1920s, came from Andalusia (Table 1), specifically from the rural areas of eastern Andalusia, which was extremely depressed economically. ${ }^{9}$ Their literacy level was very low (40\% for immigrants and $28 \%$ for Andalusian immigrants, Table 2$)^{10}$ which is not so surprising when three factors are taken into account: the enormous shortcomings in women's education in these working women's places of origin, ${ }^{11}$ the interruption in their schooling caused by the civil war and the process of immigration itself during the challenging years of the post-war period, and the obstacles to schooling under Francoism. $^{12}$

\section{[Table 2 near here]}

Their reproductive rates, with an average of four children, differed considerably from those of the first generation, and was practically double that of the Catalan, and even the

\footnotetext{
${ }^{9}$ The farm crisis, due to the phylloxera plague that occurred in the last quarter of the nineteenth century in the Catalan countryside, drove migration to Barcelona (Recaño, 1989 quoted by López Gay, 2008:150). The urban migration from cities that had traditionally sent people to the Catalan capital was also significant. Catalans, as well as migrants from Valencia and Aragon, were largely skilled workers and artisans attracted by the great industrial growth of the city (Oyón, 2001: 52-60). Later, the migration from Murcia and Andalusia was from the farming and mining crisis areas where the people were mainly unskilled workers attracted by the second industrial revolution, and, especially, by the large public works executed in the city during Primo de Rivera’s dictatorship (Tatjer; 1980, Oyón, 2001).

${ }^{10}$ This is very low compared to the first generation as well as to the $71.90 \%$ general female literacy rate in the city in 1930 and $64.20 \%$ in 1950 (according to data from the National Population Census of 1930 and 1950).

${ }^{11}$ In 1930, the illiteracy rates for women in the western part of Andalusia ranged between 60-69\% (Capel, 1982, pp. 376-377).

12 During Francoism, the high rates of school absenteeism among girls led to the gradual growth in the proportion of illiterate women in the total population of the illiterate. By the early 1970s, there were more than twice as many illiterate women than illiterate men (Vilanova \& Moreno, 1992, pp. 302-337).
} 
Spanish - which was traditionally higher than the Catalans' - averages. ${ }^{13}$ Therefore, younger women were marrying earlier (Table 3) and having more children, which more closely resemble the behaviours of the population in their areas of origin than to that of the Catalan people. Surely, this trend was fostered by the process of the segregation and concentration of working-class immigrants in particular areas of Barcelona.

\section{[Table 3 near here]}

The second-generation women workers lived in the slums that proliferated in the coastal areas of El Poblenou and La Barceloneta, which became some of the poorest parts of the city, from the end of the nineteenth century. This process, slow until the 1930s, was exacerbated during the post-war period and even more so in the third wave of immigration to Barcelona in the 1960s (Oyón, 2008), after the Francoist authorities had completely stopped the building of more accommodation in the city (Bordetas, 2009b). As a result, younger women had little chance of escaping from marginal dwellings in the slums. An experience that had undoubtedly been much shorter for the women who had arrived earlier became longer and longer until practically permanent. ${ }^{14}$

In summary, the more pronounced proletarian profile among the women born after the mid-twenties reflects the growth in the number of rural immigrants coming to the city to escape from the extreme poverty of their origin areas during the first third of the twentieth century. However, it is also undoubtedly indicative of the hiring policies of

\footnotetext{
${ }^{13}$ In Catalonia, the final number of offspring among the women born in the period 1916-1944 rose from 1.67 to 2.30, though in Spain it decreased slightly from 2.61 to 2.59 (see data in Cabré, 1999, p. 67).

${ }^{14}$ One case, probably among the most extreme, is M.M.R. Born in 1918 in La Rábita (Granada), she lived in a slum in the neighbourhood called Gas for at least 25 years.
} 
the metallurgical factories in the areas of El Poblenou and La Barceloneta where all of these women lived. ${ }^{15}$ A representative example of these policies can be seen in the firm HGB, which, over the course of the first third of the twentieth century, and especially after the Spanish Civil War (1936-1939), gradually hired female workers from the poorest segments of the working class. The implementation of increasingly sophisticated production systems allowed the firm to hire unskilled workers who were very young when they entered the factory and who were usually fired just a few months later.

\section{The reconstruction of the women's labour activity rate}

\subsection{Sources and methodology}

The reconstruction of female labour force participation is a complex issue as the sources usually obscure women's work. Even the source that has most commonly been used in Spain in recent years, the municipal censuses, systematically underreport female work. Therefore, in Spain - as in other European countries - historians are increasingly turning to alternative sources from the public administration and private firms themselves in order to correct the female activity reported in the censuses. ${ }^{16}$ The source used here to make this correction is the social security contribution records for the province of Barcelona, which have been kept from 1921 to the present.

The social security contribution records of the women who worked at HGB at some point in their lives shed light on their time at the firm but also allow a reconstruction of

\footnotetext{
15 In Sant Martí de Provençals there were 429 metallurgical companies in 1933. By 1963 there were 1,826 , or $26 \%$ of the total number of companies in the district (Nadal \& Tafunell, 1992, p. 213).

${ }^{16}$ A state of the art of the underreporting of women's work in the official statistical sources can be found in Borderías et al. (2011). On the reasons for underreporting: Humphries \& Sarasúa (2012).
} 
their complete working lives. This was done, first, by creating a database with the dates of registration and deregistration in the contribution records produced by HGB between 1921 and 1978, which resulted in a list of 727 women who worked for the firm during that period. ${ }^{17}$ Then, these women's reported registrations and deregistrations in various social insurance schemes up to 2004 were located, ${ }^{18}$ which yielded information on the other companies where they worked during their lives. Also, the periods when the women did not contribute were incorporated into the database in order to check their status in the labour market (working/not working) from the moment of their births to the moment of the deaths, in the event that these occurred before 2004 (Figure1, 1.a).

Next, the censuses were searched to determine which women were living in Barcelona between 1930 and 1950. As previously mentioned, a total of 431 were identified: 233 women in 1930, 271 in 1940, 166 in 1945 and 309 in $1950 .{ }^{19}$ Not all of the women were recorded in each census as some had not yet been born or some were not residing in the city at the time or some had left the city temporarily during the civil war and its aftermath. Nevertheless, an important objective was achieved: in most cases, their work activity at different stages in their family life cycles could be determined (Figure 1, 1.b).

\footnotetext{
${ }^{17}$ Until 1946, it was not mandatory to report children under 16 years old to social security even though the legal working age was 14 years of age. Therefore, it may be that there were more than these 727 women working in HGB during this period. However, the list of workers drawn from the company records, partially preserved since 1940 , provides no other names.

${ }^{18}$ The first of these schemes is the Retiro Obrero Obligatorio (Mandatory Working Class Retirement), the first pension system in Spain, in force between 1921 and 1939. The second is the Seguro Obligatorio de Vejez e Invalidez (Compulsory Old Age and Disability Insurance), in force from 1940 to 1959 and the third, Social Security, a comprehensive social support system (pensions, disability, unemployment), was created in 1960.

${ }^{19}$ All their data were entered into the database, including the data of the other members of the same household (sex, age, birthplace, marital status, literacy, occupation, legal length of residence in the city, parenthood with the head of the household) as well as the data related to the residence itself (street, number, neighbourhood, etc.).
} 
By cross-checking the sources it was possible to reconstruct the position of this group of women in the labour market on the date the censuses were conducted, which was the $31^{\text {st }}$ of December of each year (Figure 1,1.c), in order to calculate: a) the underreporting of the employment of these women in the Barcelona Municipal Censuses from 1930 to 1950; and b) their labour force participation rate at any given date within that period (Figure 1, 1.e).

There are, however, some limitations to using the social security records. During the period studied, these records provide information only about the regulated labour market. Specifically, the records cover participation in the secondary sector. It is important to keep in mind that a traditional aspect of the Spanish labour market, especially during the Franco years, was the large number of women in informal employment (Sarasúa \& Molinero, 2009). Also, during the dictatorship, corporate fraud in social security was very high. ${ }^{20}$ There is no doubt that these are the most important limitations of the social security contribution records when reconstructing female activity rates. However, the sources used complement each another: the social security records make it possible to recover a large number of these women's occupations that went unreported in the municipal censuses, and the municipal censuses do reveal a number of informal occupations for which contributions were made. ${ }^{21}$

\subsection{Underreporting}

\footnotetext{
${ }^{20}$ For instance, in the factories for the manufacture of "mantecados" (a Christmas sweet made of flour, almonds and lard) in Estepa (Seville), women were already working without a signed contract in the early twentieth century, a practice which was maintained during Francoism (Téllez, 2002)..

${ }^{21}$ See the example of the Personal_Id 27 in the figure 1).
} 
Among the women who were working in the labour market when the municipal censuses were carried out during the period from 1930-1950, their work went undisclosed to a considerable degree: no paid activity was reported in $45-60 \%$ of the cases. While no relation can be established with their place of origin or literacy level, underreporting can be linked to two other variables. One is marital status: underreporting was especially prevalent among married women. Indeed, the convention was to record a woman as "housewife" in the censuses, particularly for women at ages when their number of children was higher. However, underreporting was also very high among single women and widows (Table 4). ${ }^{22}$ In these latter cases, underreporting did fall substantially in the post-war years, a shift connected to the increase in the number of forms signed by the women themselves.

[Table 4 near here]

Accordingly, the underreporting of these women's employment also appears to be related to who signed the census forms. ${ }^{23}$ So, although underreporting is high when a woman signed the form, especially if she was married, it is significantly higher when the man of the household, which was most commonly the case, or the census taker did so (Table 5). This occurred particularly among married women: the level of underreporting of their work in 1940 and 1945 was almost two times higher when the

\footnotetext{
${ }^{22}$ This has also been observed in other Catalan localities and among the women working at the textile firm La España Industrial (Borderías et al., 2011; Borderías, 2012).

${ }^{23}$ While it is true that the signature on the form does not necessarily correspond to the person who completed it, examination of the forms supports this generally being the case and that this approach is therefore a sound one.
} 
man of the household signed. ${ }^{24}$

\section{[Table 5 near here]}

Therefore, in this case, the extremely high level of underreporting of women's employment can be accounted for, in part, by the fact that the women themselves were not the ones reporting their employment, which instead was done by the men, who were supposedly the main breadwinners in their families. This is clearly the image reflected in the municipal censuses in terms of the families' employment strategies if the women's declarations are taken at face value. Without cross-checking and correction, the municipal censuses cannot be used for a valid analysis of the factors determining women's labour force participation. Thus this analysis is restricted to the working women for which information exists on their position in the regulated labour market throughout the period, without including the other women living in their households.

\subsection{Labour force participation, age and business policies}

According to the social security contribution records, the labour force participation rate - primarily in industry - for this group of women passed through three stages between 1925 and 1955. In the first stage, the rate increased from 1925 to 1930 , rising from $37 \%$ to a peak of nearly $45 \%$. Then there was a period of decline during the thirties, a fall

\footnotetext{
24 This was also noted by August (1994). Indeed, I have found that the declarations of employment of all the women in the household were amended by male heads of household when they signed the forms, changing what was clearly a paid job to that of a "housewife" ("sus labores"). This is the case with J.P.H., 44 years old, and her daughter of 19, who declared themselves as "machine operators" in 1950, but whose husband wrote over these entries, putting "housewife". The reconstructed working life of J.P.H. indicates that her declaration in the census refers to her job as a seamstress operating a sewing machine.
} 
that was especially pronounced during the civil war. In 1938, employment among these women reached its low point for the entire period, dropping to $18.7 \%$. In the third stage beginning with the end of the war in 1939 , labour force participation rapidly recovered to $30 \%$ in the early forties and remained steady at this level until 1955 (Table 6).

\section{[Table 6 near here]}

An analysis of labour force participation rates by age group shows that the increase among these women in the second half of the 1920s occurred among younger women aged 15 to 24 , not among older women, whose labour force participation rate was very high in 1925 and then plummeted, especially those aged 35 and over. This fall became more moderate but continued throughout the 1930s, when the labour force participation rate of women under 25 also fell. After the civil war, younger women were also the main beneficiaries of the rise in employment. By contrast, the labour force participation rate for women aged 25 to 34 remained at the same level as in the pre-war years and the rate for women aged 35 or over gradually declined, a trend that was especially pronounced among women aged 45 and over (Figure 2). In addition, there were no significant differences by place of origin — Barcelona/immigrant - in these trends.

\section{[Figure 2 near here]}

Cross-checking the names in the contribution records with the employment reported in the censuses broadly confirms these employment trends by age between 1930 and 1950 . The cross-checking also confirms, however, that the rates were substantially higher in all age groups, but especially among younger women if we compare them with the rates 
calculated based solely on the contribution records, and especially among middle-aged women if we compare them with the rates calculated based solely on the census statements. Thus, between 1930 and 1950, the employment of young women (15-24 years of age) held relatively steady, not in the region of $30 \%$ as the contribution records indicate, but in the range from $60-70 \%$, with the exception of 1940, a time at which unemployment affected them more severely than it affected middle-aged women. It is well established that youth unemployment is typical in times of crisis, especially among those with a lower level of education. Indeed, employment among women aged 25 to 34 still remained steady, but in the region of $45 \%$ and not $20 \%$ as the census data suggests. Throughout the period, the only substantial decline in labour force participation occurred among women aged 35 and over, and especially among those 45 and over. Even so, their labour force participation rate continued to hold in the region of $30 \%$ between 1940 and 1950 (Table 7).

\section{[Table 7 near here]}

The cross-checking also brings to light the practice of child labour that is almost completely undisclosed in the contribution records. The census data indicate that work by these women when they were under the age of 15 was not uncommon in 1930 and that this practice increased in the post-war period (Table 7). They had to enter the labour market early and they did so at the expense of their schooling. This shift occurred when the percentage of their male relatives aged 13 and 14 receiving schooling was on the rise and, as a result, whose labour force participation rate was declining, which indicates 
that the girls' incorporation in the labour market helped to extend their brothers' schooling. ${ }^{25}$

Between 1930 and 1950, there was a decline in factory employment among the group of women studied. Contrary to what the census data suggest, however, the decline began not in the post-war period, but in the early 1930s. It was caused, therefore, by the economic crisis in the metallurgical sector, where most of the women worked (table 8). Although the sector experienced a mild recovery by the mid-thirties, the crisis dovetailed with the outbreak of war and the post-war recession. Indeed, once the civil war was over, the labour force participation rates of women aged 34 or under were soon similar to those in the early 1930s. The stability of these rates through the mid-fifties, interrupted only in the immediate aftermath of the war, suggests that the establishment of marriage bars by the Franco regime's labour regulations, which were implemented in the metallurgical sector in 1946, had no impact on these women's factory employment. ${ }^{26}$ In fact, from 1921 to 2004 , the percentage of women abandoning the labour market definitively before the age of 25 , when almost all of them had married and had had their firstborns, remained stable around $25 \%$, which also points to the same conclusion ([name deleted to maintain the integrity of the review process], 2016: 65).

\section{[Table 8 near here]}

\footnotetext{
25 The decline in families' economic resources typically affects the schooling of girls more than that of boys, as girls more often end their education to enter the labour market early and thereby keep the boys from having their education affected by recession (Borderías, 1991, p. 480).

${ }^{26}$ The same occurred in other sectors, including some in which the marriage bar was compulsory. In the textile and clothing industry in Madrid, however, the norm did not involve permanently leaving the factory. Women left the job when they married to collect their "dowry" but they were re-hired immediately by the same firm or by another one (Díaz Sánchez, 2003: 230).
} 
The reversal in industrial employment from 1940 onwards is only confirmed in the case of women aged 35 and over. This reversal, however, had begun before the crisis of the thirties - at the latest, by the mid-twenties - as a direct consequence of the hiring policies in the metallurgical sector. Thanks to the mechanisation process launched in the late nineteenth century by manufacturers of metal objects in order to drive down costs to compete against an increasing number of foreign manufacturers, the way was gradually cleared for women to take certain semi-skilled and unskilled jobs. However, as mechanisation and feminisation of the work proceeded, the businessmen also made the women's jobs more precarious. By putting bonus payment schemes in place, they succeeded in forcing work rates higher, enabling them to reduce their demand for female workers. The adoption of increasingly sophisticated machinery also contributed to lowering the required levels of skills so that the owners became increasingly inclined to hire very young, unskilled and cheaper women. ${ }^{27}$ This policy intensified during the 1920 s and $1930 \mathrm{~s}^{28}$ and even more so in the post-war period, when the labour legislation in the sector sharpened the wage disparity between young women and their adult counterparts: in 1936, the salary of a 15- to 17-year-old assistant was about $60 \%$ of that of a skilled adult female worker. From the end of the civil war and, at least until the mid-forties, the salary of a 14-year-old assistant was only $28 \%$ of that of an adult female

27 Thus, for example, in 1921, the Torres $i$ Bordas Company (Barcelona) advertised a cutting and stamping press stating that "generally young girls worked as operators" of these machines (La Industria Metalúrgica, May 1921, 2: 10).

${ }^{28}$ Thus, as an example, in the metal box company G. de Andreis-Metalgraf Española (Badalona) "a man, earning 9.5 pesetas per day, produced 6,000 cover caps; and now, a woman, with a 5 peseta daily wage, produces 9,000, earning a one peseta production bonus". Moreover, "in the automatic capping machines three women produced 6,000 boxes [...] now two women produce 9,000" (Solidaridad Obrera, 22/10/1935, 1098: 6). 
worker. ${ }^{29}$ This further encouraged the businessmen to increase their turnover of female staff to such an extent that the sector became characterised, until at least the end of the 1950s, by its extreme youthfulness (Table 9), while in the case of the male workforce the age distribution remained the same after the civil war. ${ }^{30}$

\section{[Table 9 near here]}

Due to these policies, it became increasingly difficult for the working women in this study as they grew older to find a job in the metallurgical sector, where most of them had started their working lives. As a result, the post-war years saw these women pushed out of the metallurgical sector amid widespread industrial recession and rising unemployment, with a concurrent rise in their number in the service sector (Table 8), specifically in lower-status positions such as those as cleaners - a job that in the formal labour market was performed in shops or in the offices of the public administration - or as porters in residential buildings. ${ }^{31}$

29 According to the 1936 Metallurgical Collective Bargaining Agreement (Bases de Trabajo de la Metalurgia, provincia de Barcelona) and the 1938-1946 National Iron and Steel Industry Labour Regulations (Reglamentaciones Nacionales para la Industria Siderometalúrgica).

30 There are no available data on the age distribution of the male workforce in the metallurgical industry in Barcelona after 1940. However, in the specific case of the firm HGB, the owners used mechanisation to feminise and erode the labour conditions in the mechanical processing phase of small- and mediumsized tin boxes from the late nineteenth century. The firm did not hire unskilled young male workers in significant numbers until the fifties and sixties, when the jobs in the areas where the male workforce predominated were mechanised.

${ }^{31}$ For more information on the characteristics of these women's labour trajectories: [name deleted to maintain the integrity of the review process] (2016). 


\section{Labour force participation and family life cycle}

\subsection{The impact of marriage}

According to census information, marriage had a considerable negative impact on the working lives of the women (Table 11). However, as previously stated, only approximately $25 \%$ of these women completely abandoned the labour market before turning 25. Indeed, using only the municipal censuses, the conclusion could be drawn that employment was a relatively minor phenomenon among the married women in these families. However, this is inconsistent with the evidence, which indicates that their families' living conditions worsened considerably between 1930 and the post-war years and, therefore, they needed to increase earnings. ${ }^{32}$

\section{[Table 10 near here]}

The correction of the census declarations clearly shows that married women's work was quite important to their families. Certainly, the rates calculated through cross-checking the sources shows a decline in employment among the married women in the group between 1930 and 1950, but this also occurred among the widows. The decrease, therefore, is not related to marital status, but to age and also to the composition of households and family strategies for the distribution of productive and reproductive work. In particular, the drop in employment among the married women did not affect the youngest women, those who married in the 1940s and who were the daughters, daughters-in-law, nieces and so forth within the households. The decline occurred only

\footnotetext{
32 In 1930, the average number of people per household in this group was 5.26, which is higher than the Barcelona average (4.4), and $42.16 \%$ of the homes had more than six people living together. By 1950 , the average number of household members rose to 6.21 and the percentage of homes with six or more residents climbed to $52 \%$.
} 
among the women of the previous generation, the heads of household and their sisters and sisters-in-law, aunts and the like (Table 11). As noted earlier, they had fewer job opportunities because of their age and this made them perfect candidates to assume the heavier burden of domestic chores in crowded households. This burden was to become greater in the post-war period, especially in environments like the slums, where there were no services, not even running water.

\section{[Table 11 near here]}

\subsection{The impact of maternity}

Before the Spanish Civil War, the burden of having dependent children did not have a determining influence on the labour force participation of the working women in the study. In 1930, the gap between the labour force participation rates of married women without children and those who had children was a little more than $10 \%$, and almost $40 \%$ of the married women with three or more children under the age of 15 worked. The negative impact of the number of children on labour force participation rates worsened after the war, when the rate was lower than in 1930 for the same number of children (Table 12). This decline, however, should not be linked to more women leaving work completely as a result of the birth of their children after the war. The reproductive burden, rather than causing their definitively leaving the labour market, led only to an interruption, a feature typical of these women's working lives, especially in the middle stages of the life cycle ([name deleted to maintain the integrity of the review process] 2013: 264-286; 2016:65).

\section{[Table 12 near here]}


An examination of these women's work situation at the time of their children's births shows that, indeed, between 1921 and 1939, their labour force participation rate did not fall significantly until the third child was born. By contrast, in the post-war period, the figure for employed women dropped quite a bit lower when their second child was born and even lower with the arrival of the third, at which point only $10 \%$ were working (Table 13). However, the issue that influenced the women's decision to stop working was less the number of children than the fact that they were born in quick succession. Thus, the opportunities for a mother to continue working before the war did not notably fall until the birth of her third child, provided that the third child was born at least two years after the second child (23.53\%) (Table 13).

\section{[Table 13 near here]}

Also, if married women left work after the birth of their children, they rejoined the labour market as soon as possible. Between 1921 and 1939, nearly $60 \%$ of withdrawals, when the leaving coincided with the birth of a child, lasted less than three months. In the years of Francoism, by contrast, the percentage of long-term withdrawals after the birth of a child rose sharply, in keeping with what has been observed above (Table 15). This fact is undoubtedly related to the rising fertility rate of the working women born from 1914 onwards and therefore with falling childbirth intervals. As we have already seen, it is also clear that the hiring policies in the metallurgy sector - which only hired very young women - did nothing to encourage mothers to return to the labour market. The widespread slump in industry and rising unemployment made this return even more difficult. Certainly the policy of family subsidies, which were paid for the second child 
under 14 years of age, implemented by the Franco regime in 1938 contributed to lengthening the periods that these working women remained outside the industrial labour market. However, this assistance did not fulfil these families' needs for supplementary income. To the contrary, as we shall see, when young married women left factory work to take care of their children, it had serious consequences on the living standards of the family if their lost wages were not offset by the earnings of another relative. Thus, the woman's loss of income from the formal labour market at the most critical period in the family life cycle led to a reliance on strategies such as subletting to cut expenses or having lodgers to earn income.

\section{[Table 14 near here]}

\subsection{The influence of the family structure on the labour force participation of married women}

Co-residence in extended and multiple family households was an economic strategy employed by the families of the women in the study to cope with the extremely precarious circumstances in which they lived even before the civil war. Thus, among these families, the predominant household structure in 1930 was the extended and multiple one, which accounted for $37.25 \%$ of households, ${ }^{33}$ a figure that reached almost 50\% from 1940 to 1950, and which was more common in the life cycle stages when the

\footnotetext{
${ }^{33}$ This figure is higher than the Barcelona average in 1930, which was $24.95 \%$ according to the census data of a random sample of 1,000 families. This sample forms part of the database compiled for the projects: La reconstrucción de la actividad económica en la Cataluña Contemporànea (siglos XIX-XX): trabajo y movilidad social (HAR2008-01998/HIST) [The Reconstruction of Economic Activity in Catalonia: Work and Social Mobility] and La reconstrucción de la actividad económica en la Cataluña contemporánea (siglos XIX-XX: trabajo, demografía y economía familiares (HAR2011-26951) [The Reconstruction of Economic Activity in Catalonia: Work, Demography and Family Economies]. PI: Cristina Borderías.
} 
active/inactive ratio was particularly adverse. Beyond that, however, did co-residence enable women to continue working in the formal labour market? To answer this question, we first examine the work strategies of nuclear families.

In 1930, among nuclear families, couples without children largely relied on the wife's income $(57.1 \%)$ to enhance the husband's income. This is unsurprising if we take into account the high cost of living in Barcelona in 1930 and the low wages earned by these workers, most of whom were unskilled. ${ }^{34}$ The women not in work had abandoned their jobs when they were still very young, probably when they married, and did not return to work. The loss of this income was offset by costcutting. Undoubtedly, rent was the most burdensome expense in family budgets. For this reason, some of these couples were forced into lodging and subtenancy options (21.4\%). Sharing accommodation was also common among couples with dependent children (14.3\%) if the wife did not work. Indeed, this was the most prevalent situation $(67.9 \%)$ at the time, for practically all of the women had two or more children, where one was less than a year old. The situation, however, was not the same for wives who did work (35.7\%). The youngest children of these women were generally older than one year of age. In addition, in a large proportion of these families, the children entered the labour market as soon as they were old enough to do so ( $85.7 \%$ in 1930). At that point, most of their mothers were working (71.4\%), doubtless because the income of their children, still very young, was insufficient to make up for the women's lost income without putting the family budget

\footnotetext{
${ }^{34}$ According to the anarchist newspaper Solidaridad Obrera (CNT), which initiated a campaign to denounce the abusive rents in the city in October 1930, rent could represent 20-25\% of a worker's wage, something that with rising prices made "the economic situation of those people forced to live with very low pay for their work" very difficult (Solidaridad Obrera; 19/10/1930, 41: 8). In fact, the CNT encouraged a rent strike in Barcelona in 1931(Rider, 1986).
} 
in jeopardy. By 1950, however, a large number of the children had already replaced their mothers in the labour market (Table 15).

\section{[Table 15 near here]}

Taking in paid lodgers, which was one of the few types of unregulated work reported in the censuses, was not common in 1930, but grew considerably in the post-war period. This indicates that leaving the factory did not bring an end to wage-earning activities for the older married women in the group. Rather, paid lodgings began to develop within the underground economy in the post-war period to a greater extent than in the pre-war years. ${ }^{35}$ By 1950 , nearly one-third of nuclear families $(26.15 \%)$ took in lodgers in order to cope with the deterioration of living standards and even young couples in which both spouses were working did so $(28.6 \%)$.

Nevertheless, during the post-war period, taking in lodgers was not an expedient exclusively for nuclear families. It also occurred in combination with co-residence with relatives. Indeed, while only 5\% of extended and multiple family households had lodgers and subtenants in 1930 , this figure had grown to $22 \%$ by 1950 , with in some cases abysmal conditions such as slum accommodations with more than 20 people registered as residents. This phenomenon is unsurprising in a period of economic recession, with low wages, rationing of basic consumer goods, the black market and rampant inflation.

\footnotetext{
35 During the first third of the twentieth century, married women in the Basque Country who were displaced from a male-dominated labour market - mining and steel - turned to paid lodgers as a critical source of income as an alternative to working in industry (Pérez-Fuentes, 2003).
} 
In extended and multiple families, the working lives of married women had already been interrupted more than those of their counterparts in nuclear families before the civil war. Marriage meant leaving work in most cases, at least temporarily, and married women without children worked to a lesser extent than in the households of nuclear families (Table 16). Thanks to the addition of incomes from the husband and relatives, and the reduction in costs from sharing accommodation, it was easier to forego the wife's income and families all pitched in to take on the greater domestic burdens of an extended and multiple family household. When economic necessity dictated, however, the extended and multiple family household could also turn more intensively to the work of all of its members, including the married women, who were able to coordinate their work schedules with those of the other women in the house in order to cope with both wage-earning jobs and the household chores.

\section{[Table 16 near here]}

Contrary to what occurred in simple households, mothers in extended and multiple family households with dependent children worked more when they had two or more dependent children (Table 17), and they did so more often when there was an older woman in the household, typically their mother or mother-in-law, because she would take on looking after the children and doing the household chores. This effort would decrease when the children reached working age, a stage at which women in this type of household worked in smaller numbers than in nuclear households. Thus, in response to the question regarding whether co-residence facilitated continuity of work in the formal labour market for these women, the answer must be no. Their entrance and withdrawal 
from the labour market depended on the family's economic needs and on the availability of other members of the family to work and/or take on the household chores. In any event, extended and multiple family structures offered families greater opportunities to adapt to different situations.

\section{Conclusions}

In conclusion, it is clear that a reliable reconstruction of women's employment is not possible based solely on the statement of employment reported in the municipal censuses. As other studies have already shown, underreporting in the municipal censuses among the working women in study - who were members of the poor working class - was extremely high, particularly in the case of married women. The correction of the activity recorded in the census using social security contribution records leads to the conclusion that supply factors like marriage or maternity were not determining factors in the women's definitive abandonment of the labour market. Their labour force participation only fell when they had a high number of very small children. Before the civil war, the women in this study typically left work for only a very short time due to maternity. After the war, these periods away from work grew much longer. On one hand, the women shouldered a greater reproductive burden in a shorter period of time. On the other, from the demand-side, their labour opportunities were limited. It was much more difficult for them to return to the formal labour market during an economic recession and the consequent higher rates of unemployment. These challenges were compounded by the hiring policy in the metallurgy industry, where most of the women had worked in their youth because the sector hired young girls almost exclusively, a practice which would radically change the age composition of the female workforce after the war. 
Francoist labour regulations such as the establishment of marriage bars - which were implemented in the metallurgical industry in 1946, as well as in others - also made their permanence in the industrial labour market difficult. Moreover, the Francoist policy of the payment of a family subsidy made the lengthening of the absence from the labour market more bearable. However, even with these benefits, many of these families were forced to cut costs by becoming lodgers or subtenants or had to increase their income by taking in paid lodgers and subtenants, one of the irregular jobs that are reported in the censuses and the prevalence of which rose sharply in the 1940s.

For these women, the frequency of their children's births was not the only supply-side factor affecting their continuing in work. The family structure also appears to have had a strong influence. When they lived in a nuclear family household, it was difficult for them to remain out of the labour market for long while their children were small. Not even in the initial years after their children entered the workforce did they cease working. When they did leave work, it was very often at the expense of no longer maintaining an independent household. In some cases, couples opted to become lodgers in order to reduce the largest expense in their budget: rent. In most cases, however, this decision enabled them to look after their children while at the same time earning "under the table" income by taking in lodgers. After the civil war, this strategy meant they could keep their subsidies, which they would have lost if they had returned to regulated work.

Living in an extended and multiple family household, the predominant structure among the families, did not contribute to the continued employment of married women. In 
general, marriage meant that many became responsible for the domestic workload. Bearing in mind that there were a high number of members in these households, the burden could be very intense, especially in the post-war period, when sourcing basic foodstuffs could occupy much of the day. The loss of their wages in the early stage of marriage was offset by income from other relatives, who were normally unmarried. Nevertheless, when the number of mouths to feed went up, that is, when they had more children, these women went out to work in equal or greater numbers than those in nuclear households. Household chores were then left in the hands of older women or were shared with the other women who worked outside the home. 


\section{References}

Alabart, A. (1982). Els barris de Barcelona $i$ el moviment associatiu veïnal [The neighbourhoods in Barcelona and their Associative Movement]. Tesis Doctoral, Universitat de Barcelona.

López-Gay, Antonio (2008). Canvis residencials $i$ moviments migratoris en la renovació poblacional de Barcelona. Barcelona. Consell de Treball, Econòmic i Social de Catalunya.

August, A. (1994). How Separate a Sphere? Poor Women and Paid Work in LateVictorian London. Journal of Family History, 19 (3), 285-309.

Babiano, J. (2005). Mercado laboral y condiciones de trabajo durante el franquismo: algunas características, algunos efectos [Labor market and working conditions during the Franco regime: some features, some effects]. In M. Ortiz (coord.), Memoria $e$ historia del franquismo. V Encuentro de Investigadores del Franquismo [Memory and History of Francoism. V Meeting of Francoism Researchers] (pp.213-234). Cuenca: Ediciones de la Universidad de Castilla-La Mancha.

Borderías, C. (1991). Proyectos, estrategias familiares y trayectorias sociales femeninas [Projects, Family Strategies and Female Social Trajectories]. In J. Prat et al. (eds.), Antropología de los pueblos de España [Anthropology of the Spanish Countries] (pp. 475-484). Madrid: Taurus Universitaria.

Borderías, C. (1993a). Entre líneas: trabajo e identidad femenina en la España contemporánea: la Compañía Telefónica, 1924-1980 [Work and Female Identity in Contemporary Spain: The Telefónica Company]. Barcelona: Icaria.

Borderías, C. (1993b). Emigración y trayectorias sociales femeninas [Emigration and Female Social Trajectories]. Historia Social, 17, 75-94. 
Borderías, C. (2002). Women and Work in Barcelona, 1856-1936. In A. Smith (ed.), Red Barcelona: Social Protest and Labour Mobilization in the Twentieth Century (pp. 162-166). London: Routledge.

Borderías, C. (2003). La transición de la actividad femenina en el mercado de trabajo barcelonés (1856-1930): teoría social y realidad histórica en el sistema estadístico moderno [The Transition of Female Labour Force Participation in the Labour Market of Barcelona: Social Discourse and Historical Reality in the Modern Statistical System]. In C. Sarasúa \& L. Gálvez (eds.), ¿Privilegios o eficiencia? Mujeres y hombres en los mercados de trabajo [Privileges or efficiency? Women and Men in the Labour Markets] (pp. 242-273). Alicante: Publicaciones de la Universidad de Alicante.

Borderías, C. (2004). Women's Work and Household Economic Strategies in Industrializing Catalonia. Social History, 29 (3), 373-383.

Borderías, C. (2010). La reconstrucción de la tasa de actividad en la Cataluña industrial: nuevas evidencias sobre los determinantes del empleo femenino (Siglos XIXXX) [The Reconstruction of the Labour Force Participation in the Industrial Catalonia]. Paper presented. IX Congreso de la Asociación Española de Demografía Histórica.

Borderías, C. (2012). La reconstrucción de la actividad femenina en Cataluña circa 1920 [The Reconstruction of the Female Labour Force Participation in Catalonia, circa 1920]. Historia Contemporánea, 44, 17-48.

Borderías, C. (2013). Revisiting Female Labour Force Participation in Textile Catalonia (1920-1936). Feminist Economics, 19 (4).

Borderías, C. \& López Guallar, P. (2003). A Gendered View of Family Budgets in Midnineteenth Century Barcelona. Histoire \& Mesure, XVIII (1/2), 113-146.

Borderías, C., Villar, C. \& González-Bagaria, R. (2011). El trabajo femenino en la Cataluña industrial (1919-1930): una propuesta de reconstrucción [Women’s Work in 
the Industrial Catalonia: A Proposal for its Reconstruction]. Revista de Demografía Histórica, 29 (1), 55-88.

Borderías, C. \& Ferrer, Ll. (2015). Hogar e industria textil. Mercado de trabajo y estrategias familiares en Catalunya (1900-1936) [Home and textile industry. Labour market and family strategies in Catalonia (1900-1936)]. Historia Social, 81: 3-27.

Borrell, M. (2016). El servei domèstic a la ciutat de Barcleona, 1900-1950 [Domestic Service in the city of Barcelona, 1900-1950]. Tesis Doctoral. Universitat de Barcelona.

Cabré, A. (1999). El sistema català de reproducció [The Catalan System of Reproduction]. Barcelona: Enciclopèdia Catalana.

Campos, C. (2013). La tasa de actividad femenina a mediados del siglo XIX en Andalucía: el caso de Antequera [The Female Labour Force Participation Rate in the Mid-nineteenth Century in Andalusia: the Case of Antequera]. Investigaciones de Historia Económica, 10 (3), 191-201.

Camps, E. (1998). Transitions in Women's and Children's Work Patterns and Implications for the Study of Family Income and Household Structure: A Case Study from the Catalan Textile Sector (1850-1925). The History of the Family, 3 (2), 137-153.

Camps, E. (2004). Teixint la ciutat fàbrica: la formació de la primera Manchester catalana [Weaving the factory-city: the formation of the first Catalan Manchester]. Recerques, 47-48,81-106.

Capel, R.M. (1982). El trabajo y la educación de la mujer en España 1900-1936 [The Work and the Education of the Women in Spain, 1900-1936]. Madrid: Ministerio de Cultura.

Costa, D.L (2000): From Mill Town to Board Room: The Rise of Women's Paid Labor. Journal of Economic Perspectives, 14 (4), 101-122. 
Domènech, J. \& Elu-Terán, A. (2008). Women's Paid Work in an Urban Developing Economy. Barcelona in 1930. Revista de Historia Económica, 3, 375-402.

Fernández Gómez, J.A. (2000). La doble aportación laboral de las mujeres (1940-1965): estrategias familiares en los hogares obreros del sur de Madrid para mejorar la economía doméstica [The Double Labour Contribution of Women (1940-1965): Family Strategies in Working Class Households in Southern Madrid]. Revista de dialectología y tradiciones populares, LV (2), 175-196.

Ferrer, Ll. (1995). Notas sobre el uso de la familia y la reproducción social [Insights on the use of family and social reproduction] . Boletín de la ADEH, 13, (1), 11-27.

Garrido-González, L. (2015). La tasa de actividad femenina en el siglo XVIII en 2 municipios andaluces: Laujar de Andarax (Almería) y Úbeda (Jaén) [Female Labour Force Participation in the 18th Century in two Andalusian villages]. Investigaciones de Historia Económica, 11, (3).

Haines, R. M. (1979). Industrial Work and the Family Life Cycle. 1889-1890. Research in Economic History, 4, 289-356.

Hareven, T. (1982). Family Time and Industrial Time. New York: Cambridge University Press.

Horrell, S. \& Humphries, J. (1995). The Explotation of Little Children: Child Labour in the British Industrial Revolution. Explorations in Economic History, 32, (4).

Humphries, J. \& Sarasúa, C. (2012). Off the Record: Reconstructing Women's Labor Force Participation in the European past. Feminist Economics, 18 (4), 39-67.

Knotter, A. (2004). Poverty and the Family-Income Cycle: Casual Laborers in Amsterdam in the First Half of the 20th Century, The History of the Family, 9, (2), 221237. 
Llonch, M. (1993). Treball femení y migracions en el mercat laboral. Vilassar de Dalt, 1910-1945 [Women's Work and Migrations in the Labour Market. Vilassar de Dalt, 1910-1945]. Memoria de Posgrado. Universitat Autònoma de Barcelona.

Llonch, M. (1994). Inserción laboral de la inmigración y sistema de reclutamiento de la fábrica textil. Vilassar de Dalt, 1910-1945 [Employment Integration of the Immigrants and the Recruitment System in the Textile Factories]. Revista de Demografía Histórica, $12(2 / 3), 149-161$.

Llonch, M. (2007). Tejiendo en red. La Industria del Género de Punto en Cataluña (1891-1936) [The Knitwear Industry in Catalonia (1891-1936)]. Barcelona: Publicaciones de la Universitat de Barcelona.

López Guallar, P. (2004). Naturales e inmigrantes en Barcelona a mediados del siglo XIX [Autochthonous and Immigrants in Barcelona in Mid-nineteenth Century]. Barcelona Quaderns d'Història, 11, 69-92.

Miret, P., Alustiza, A. \& Cámara, N. (2001). Evolución de la actividad en España según grupos de edad y sexo, 1940-2000. El nivel de instrucción y la situación familiar como variables explicativas [Evolution of The Labour Force Participation Rate in Spain by Age Groups and Sex, 1940-200. The Education and the Family Situation as Explanatory Factors]. Papers de Demografia, 195.

Muñoz, L. (2012a). Actividad femenina en industrias pesqueras de España y Portugal (1870-1930) [Female Labor Force Participation in the Fisheries in Spain and Portugal (1870-1930)]. Historia Contemporánea, 44, 49-71.

Muñoz, L. (2012b). Women in the Rural and Industrial Labor Force in Nineteenthcentury Spain. Feminist Economics, 18 (4), 121-144.

Nadal, J. \& Tafunell, X. (1992). Sant Martí de Provençals. Pulmó industrial de Barcelona (1847-1992) [Sant Martí de Provençals. The Main Industrial District of Barcelona]. Barcelona: Columna Edicions. 
Organización Sindical Española-Servicio Sindical de Estadística (1959). El trabajo femenino en centros de más de 50 productores [Women's Work in Factories with more than 50 workers]. Madrid: Imp. Samarán.

Oyón, J.L. (2008). La Quiebra de la ciudad popular: espacio urbano, inmigración y anarquismo en la Barcelona de entreguerras, 1914-1936 [The Rupture of the Popular City: Urban Space, Immigration and Anarchism in the Barcelona of the Interwar Period, 1914-1936]. Barcelona: Ediciones del Serbal.

Oyón, J.L., Maldonado, J. \& Griful, E. (2001). Barcelona 1930: un atlas social [Barcelona 1930: a Social atlas]. Barcelona: Edicions UPC.

Pérez Pérez, J.A. (2007). Trabajo doméstico y economía sumergida en el gran Bilbao a lo largo del desarrollismo: un mundo invisible y femenino [Domestic Work and Informal Economy in Bilbao during the late Francoism: an Invisible and Feminine World] . In J. Babiano (ed.), Del hogar a la huelga. Trabajo, género y movimiento obrero durante el Franquismo [From the Home to the Strike. Labour, Gender and Labour Movement during the Francoism ](pp. 77-138). Madrid: Catarata.

Pérez-Fuentes, P. \& Pareja, A. (2011). La evolución de las tasas de actividad femenina en Vizcaya (1825 -1935) a través de los padrones de población [The Evolution of the Female Labour Force Participation Rate in Vizcaya (1825-1935)]. Paper presented. X Congreso Internacional de la Asociación Española de Historia Económica.

Pérez-Fuentes, P. (2003). Ganadores de pan y amas de casa: Los límites del modelo de "Male Breadwinner Family", Vizcaya, 1900-1965 [Breadwinners and housewifes: The Limits of the "Male Breadwinner Family" pattern]. In C. Sarasúa \& L. Gálvez (eds.), ¿Privilegios o eficiencia? Mujeres y hombres en los mercados de trabajo [Privileges or efficiency? Women and Men in the Labour Markets] (pp.217-240). Alicante: Publicaciones de la Universidad de Alicante.

Pinilla, E. (1979). Estudios sobre cambio social y estructuras sociales en Cataluña [Studies on Social change and Social Structures in Catalonia]. Madrid: Centro de Investigaciones Sociológicas. 
Recaño, J. (1989). La primera fase de la transición demográfica en el área periurbana de Barcelona: L'Hospitalet de Llobregat (1825-1910). Memoria de Licenciatura. Barcelona.

Rider, N. (1986). Anarquismo i lluita popular: la vaga de lloguers de 1931 [Anarchism and Popular Struggle: The Rent Strike in 1931]. L'Avenç, 89, 6-17.

Roberts, E. (1982). Working Wives and their Families. In T.Barker. \& M. Drake (eds.), Population and society in Britain (1850-1980) (pp. 140-171). London: Batsford Academic and Educational.

Robinson, R.V. (1995). Family Economic Strategies in Nineteenth and early TwentiethCentury Indianapolis. Journal of Family History, 20 (1), 1-22.

Ruíz Franco, R. (2003). La situación legal: discriminación y reforma [The legal situation: discrimination and reform], In G. Nielfa (ed.), Mujeres y hombres en la España franquista: Sociedad, economía, política, cultura [Women and Men in Spain during Francoism: Society, Economy, Politics and Culture] (pp. 117-144). Madrid: Editorial Complutense.

Ruíz Franco, R. (2007).¿Eternas menores? Las mujeres en el franquismo [¿Eternal minors? Women during the Francoism]. Madrid, Biblioteca Nueva.

Saito, O. (1981). Labour Supply Behaviour of the Poor in the English Industrial Revolution. Journal of European Economic History, 10, 633-665.

Sarasúa, C. \& Molinero, C. (2009). Trabajo y niveles de vida en el Franquismo. Un estado de la cuestión desde una perspectiva de género [Working and living during the Francoism. An state of the art from a gender perspective]. In C. Borderías (ed.), La historia de las mujeres: perspectivas actuales [The History of Women: current perspectives] (pp.309-354) Barcelona Icaria. 
Scanlon, G.M. (1976). La Polémica Feminista en la España Contemporánea: 18681974 [The Feminist Controversy in Contemporary Spain]. Madrid: Siglo XXI.

Scott, J. W. \& Tilly, L. A. (1975). Women's Work and the Family in Nineteenth Century Europe. Comparative Studies in Society and History, 1 (17), 36-64.

Solé, C. (1981). La integración socio-cultural de los inmigrantes en Cataluña [The Social and Cultural Integration of Immigrants in Catalonia]. Madrid: Fundación Juan March.

Tatjer, M. (1980). La inmigración en Barcelona en 1930: los andaluces en la Barceloneta [The Immigrants in Barcelona in 1930: The Andalusian in La Barceloneta]. Estudios Geográficos, 159, 119-143.

Telo, M. (1986) La evolución delos derechos de la mujer en España [The evolution of women rights in Spain], In C. Borreguero et. al (dir.), La mujer española: de la tradición a la modernidad (1960-1980) [The Spanish Woman: from the tradition to the modernity]( pp. 81-94), Madrid: Tecnos.

Van Den Eeckhout, P. (1993). Family Income of Ghent Working-class Families CA. 1900. Journal of Family History, 18 (2), 87-110.

Vilanova, M. \& Moreno, J. (1992). Atlas de la evolución del analfabetismo en España de 1887 a 1981 [Atlas of the Evolution of Illiteracy in Spain from 1887 to 1981]. Madrid: Ministerio de Educación y Ciencia. Secretaría General Técnica. Centro de Publicaciones-Comisión Española de Cooperación con la UNESCO-[C.I.D.E.].

Vilar, M. (2006). Estrategias de supervivencia de las familias trabajadoras en el marco laboral hostil de la posguerra civil española (1939-1958) [Survival Strategies of Working Class Families during the Hostile Labour Framework during the Spanish Civil Postwar]. Sociología del Trabajo, 56, 119-163. 
Villar, C. (2013). Treball i gènere a la indústria metal-lúrgica de Barcelona (segles XIX $i$ XX) [Labour and Gender in the Metallurgical Industry in Barcelona (Nineteenth and Twentieth Centuries]. Tesis doctoral. Universidad de Barcelona.

Villar, C. (2016). Trayectorias laborales femeninas en Barcelona: de la década de 1920 a la actualidad [Female Labour Trajectories in Barcelona: from the 1920s to nowadays]. Historia Social, 84, 59-76. 
Tables

Table 1. Geographic origin of the women in the study (in \%)

\begin{tabular}{|l|c|c|c|c|c|}
\hline $\begin{array}{c}\text { Period of } \\
\text { birth }\end{array}$ & $\begin{array}{c}\text { Barcelona } \\
\text { (city only) }\end{array}$ & $\begin{array}{c}\text { Rest of Catalonia, } \\
\text { Aragón \& Valencia }\end{array}$ & Andalusia & Others & Total=100\% \\
\hline Prior to 1905 & 24,51 & 30,39 & 9,80 & 35,29 & 102 \\
\hline $1905-1924$ & 45,05 & 15,35 & 15,84 & 23,76 & 202 \\
\hline $1925-1924$ & 50,39 & 8,66 & 32,28 & 8,66 & 127 \\
\hline Total & 41,76 & 16,94 & 19,26 & 22,04 & 431 \\
\hline
\end{tabular}

Source: Barcelona municipal censuses (1930-1950).

Table 2. Literacy rates of the women in the study by place of origin (in \%)

\begin{tabular}{|l|c|c|c|}
\hline Period of birth & Barcelona-born & Immigrants & Andalusia-born \\
\hline Prior to 1905 & 48.00 & 59.74 & 60.00 \\
\hline $1905-1924$ & 78.02 & 75.68 & 68.75 \\
\hline $1925-1944$ & 70.73 & 40.00 & 28.13 \\
\hline
\end{tabular}

The literacy data is drawn from the declarations of the working women in the censuses when they were older than 11 . Only those who said that they could read and write have been considered literate.

Source: Barcelona municipal censuses (1930-1950).

Table 3. Average age at birth of first child of the women in the study by place of origin.

\begin{tabular}{|l|c|c|}
\hline Period of birth & from Barcelona & Immigrants \\
\hline Prior to 1905 & 23.77 & 25.71 \\
\hline $1905-1924$ & 23.12 & 23.23 \\
\hline $1925-1944$ & 21.71 & 19.11 \\
\hline
\end{tabular}

Source: Barcelona municipal censuses (1930-1950). 
Table 4. Under-reporting in the municipal censuses of the employed women's labour force participation by marital status, 1930-1950 (in \%).

\begin{tabular}{|l|c|c|c|c|}
\hline Marital status & $\mathbf{1 9 3 0}$ & $\mathbf{1 9 4 0}$ & $\mathbf{1 9 4 5}$ & $\mathbf{1 9 5 0}$ \\
\hline Single & 39.58 & 62.96 & 40.00 & 33.33 \\
\hline Married & 85.71 & 73.53 & 82.35 & 85.71 \\
\hline Widow & 50.00 & 30.77 & 33.33 & 14.29 \\
\hline General & $\mathbf{5 8 . 4 3}$ & $\mathbf{6 2 . 1 6}$ & $\mathbf{5 4 . 1 7}$ & $\mathbf{4 6 . 6 7}$ \\
\hline
\end{tabular}

Source: Barcelona municipal censuses (1930-1950) and the social security contribution records (1925-1955).

Table 5. Under-reporting in the municipal censuses of employed women's labour force participation by signer of census form, 1930-1950 (in \%).

\begin{tabular}{|l|c|c|c|c|c|c|c|c|}
\hline \multirow{2}{*}{$\begin{array}{l}\text { Signer of } \\
\text { form }\end{array}$} & \multicolumn{2}{|c|}{$\mathbf{1 9 3 0}$} & \multicolumn{2}{|c|}{$\mathbf{1 9 4 0}$} & \multicolumn{2}{|c|}{$\mathbf{1 9 4 5}$} & \multicolumn{2}{c|}{1950} \\
\cline { 2 - 9 } & Cases & $\begin{array}{c}\text { Under- } \\
\text { reporting }\end{array}$ & Cases & $\begin{array}{c}\text { Under- } \\
\text { reporting }\end{array}$ & Cases & $\begin{array}{c}\text { Under- } \\
\text { reporting }\end{array}$ & Cases & $\begin{array}{c}\text { Under- } \\
\text { reporting }\end{array}$ \\
\hline A man & 42.70 & 60.53 & 52.70 & 82.05 & 56.25 & 62.96 & 47.78 & 60.47 \\
\hline A woman & 17.98 & 50.00 & 33.78 & 40.00 & 22.92 & 45.45 & 31.11 & 28.57 \\
\hline Census taker & 30.34 & 59.26 & 6.76 & 60.00 & 4.17 & 0.00 & 3.33 & 100.00 \\
\hline Unknown & 8.99 & 62.50 & 6.76 & 20.00 & 16.67 & 50.00 & 17.78 & 31.25 \\
\hline Total & $\mathbf{1 0 0}$ & $\mathbf{5 8 . 4 3}$ & $\mathbf{1 0 0}$ & $\mathbf{6 2 . 1 6}$ & $\mathbf{1 0 0}$ & $\mathbf{5 4 . 1 7}$ & $\mathbf{1 0 0}$ & $\mathbf{4 6 . 6 7}$ \\
\hline
\end{tabular}

Source: Barcelona municipal censuses (1930-1950) and the social security contribution records (1925-1955). 
Table 6. Labour force participation rate: women aged 16 or over, 1925-1955.

\begin{tabular}{|l|c|c|c|c|c|c|c|}
\hline Year & $\begin{array}{c}\text { Number } \\
\text { employed }\end{array}$ & $\begin{array}{c}\text { Total } \\
\text { no. }\end{array}$ & $\begin{array}{c}\text { Labour force } \\
\text { participation } \\
\text { rate }\end{array}$ & Year & $\begin{array}{c}\text { Number } \\
\text { employed }\end{array}$ & $\begin{array}{c}\text { Total } \\
\text { no. }\end{array}$ & $\begin{array}{c}\text { Labour force } \\
\text { participation } \\
\text { rate }\end{array}$ \\
\hline 1925 & 67 & 181 & 37.02 & 1940 & 82 & 296 & 27.70 \\
\hline 1926 & 68 & 201 & 33.83 & 1941 & 91 & 304 & 29.93 \\
\hline 1927 & 70 & 212 & 33.02 & 1942 & 91 & 311 & 29.26 \\
\hline 1928 & 89 & 223 & 39.91 & 1943 & 86 & 314 & 27.39 \\
\hline 1929 & 90 & 232 & 38.79 & 1944 & 95 & 323 & 29.41 \\
\hline 1930 & 108 & 241 & 44.81 & 1945 & 101 & 329 & 30.70 \\
\hline 1931 & 102 & 243 & 41.98 & 1946 & 104 & 337 & 30.86 \\
\hline 1932 & 94 & 248 & 37.90 & 1947 & 102 & 345 & 29.57 \\
\hline 1933 & 95 & 261 & 36.40 & 1948 & 107 & 356 & 30.06 \\
\hline 1934 & 94 & 265 & 35.47 & 1949 & 106 & 363 & 29.20 \\
\hline 1935 & 90 & 266 & 33.83 & 1950 & 111 & 367 & 30.25 \\
\hline 1936 & 85 & 274 & 31.02 & 1951 & 110 & 368 & 29.89 \\
\hline 1937 & 78 & 278 & 28.06 & 1952 & 127 & 370 & 34.32 \\
\hline 1938 & 53 & 283 & 18.73 & 1953 & 120 & 371 & 32.35 \\
\hline 1939 & 61 & 290 & 21.03 & 1954 & 109 & 368 & 29.62 \\
\hline & & & & 1955 & 106 & 374 & 28.34 \\
\hline
\end{tabular}

The position in the regulated labour market (working/not working) has been observed at 31 December of each year.

Source: social security contribution records (1925-1955).

Table 7. Labour force participation rates by women's age, 1930-1950

\begin{tabular}{|l|c|c|c|c||c|c|c|c||c|c|c|c|}
\hline \multirow{2}{*}{ Age } & \multicolumn{4}{|c||}{ Contribution records* } & \multicolumn{4}{c||}{ Census data } & \multicolumn{3}{c|}{ Source cross-checking } \\
\cline { 2 - 13 } & $\mathbf{1 9 3 0}$ & $\mathbf{1 9 4 0}$ & $\mathbf{1 9 4 5}$ & $\mathbf{1 9 5 0}$ & $\mathbf{1 9 3 0}$ & $\mathbf{1 9 4 0}$ & $\mathbf{1 9 4 5}$ & $\mathbf{1 9 5 0}$ & $\mathbf{1 9 3 0}$ & $\mathbf{1 9 4 0}$ & $\mathbf{1 9 4 5}$ & $\mathbf{1 9 5 0}$ \\
\hline Under 13 & 0.00 & 2.50 & 0.00 & 0.00 & 0.00 & 0.00 & 0.00 & 0.00 & 0.00 & 2.50 & 0.00 & 0.00 \\
\hline $13-14$ & 11.11 & 0.00 & 22.22 & 0.00 & 22.22 & 0.00 & 11.11 & 40.00 & 22.22 & 0.00 & 33.33 & 40.00 \\
\hline $15-24$ & 53.06 & 31.48 & 45.24 & 49.18 & 42.86 & 24.07 & 42.86 & 40.98 & 71.43 & 48.15 & 61.90 & 62.30 \\
\hline $25-34$ & 36.84 & 32.94 & 29.73 & 38.89 & 21.05 & 17.65 & 16.22 & 31.48 & 43.86 & 40.00 & 35.14 & 48.15 \\
\hline $35-44$ & 50.00 & 36.21 & 25.00 & 25.56 & 15.00 & 22.41 & 7.50 & 15.56 & 55.00 & 39.66 & 27.50 & 28.89 \\
\hline 45 and over & 50.00 & 29.17 & 28.57 & 21.62 & 40.00 & 20.83 & 33.33 & 18.92 & 70.00 & 33.33 & 38.10 & 29.73 \\
\hline Total \% 15-65 & $\mathbf{6 2 . 7 0}$ & $\mathbf{3 3 . 3 3}$ & $\mathbf{3 3 . 0 9}$ & $\mathbf{3 7 . 5 9}$ & $\mathbf{3 2 . 9 7}$ & $\mathbf{2 1 . 0 0}$ & $\mathbf{2 4 . 4 6}$ & $\mathbf{2 5 . 5 5}$ & $\mathbf{7 6 . 2 2}$ & $\mathbf{4 1 . 5 5}$ & $\mathbf{4 1 . 7 3}$ & $\mathbf{4 5 . 6 2}$ \\
\hline $\begin{array}{l}\text { Total women } \\
\text { 15-65 }\end{array}$ & & & & & & & & & & & & \\
\hline
\end{tabular}


The position in the regulated labour market (working/not working) has been observed at 31 December of each year.

Source: Barcelona municipal censuses (1930-1950) and the social security contribution records (1925-1955).

Table 8. Employed women by economic sub-sector, 1930-1950 (in \%)

\begin{tabular}{|l|c|c|c|}
\hline Economic sub-sector & $\mathbf{1 9 3 0}$ & $\mathbf{1 9 4 0}$ & $\mathbf{1 9 5 0}$ \\
\hline Food & 1.37 & 4.31 & 4.41 \\
\hline Chemicals & 5.12 & 6.47 & 6.62 \\
\hline Graphic arts & 4.78 & 5.17 & 3.31 \\
\hline Textiles, garments and leather/fur products & 14.33 & 6.47 & 17.28 \\
\hline Wood and timber & 3.41 & 0.00 & 0.00 \\
\hline Metallurgy & 69.28 & 65.52 & 53.68 \\
\hline Other industries & 1.02 & 1.72 & 1.84 \\
\hline Commerce & 0.68 & 6.90 & 6.62 \\
\hline Public administration & 0.00 & 0.00 & 1.47 \\
\hline Personal and domestic services & 0.00 & 0.86 & 3.31 \\
\hline Profession unknown & 0.00 & 2.59 & 1.47 \\
\hline Total=100 & $\mathbf{2 9 3}$ & $\mathbf{2 3 2}$ & $\mathbf{2 7 2}$ \\
\hline
\end{tabular}

The position in the regulated labour market has been observed at 31 December of each year.

Source: Barcelona municipal censuses (1930-1950) and the social security contribution records (1925-1955).

Table 9. Breakdown of workforce in the metallurgical sector by age: Barcelona city, 1930-1957 (in \%)

\begin{tabular}{|l|c|c|l|c|c|c|c|c|}
\hline \multirow{2}{*}{ Age } & \multicolumn{2}{|c|}{1930} & \multirow{2}{*}{ Age } & \multicolumn{2}{c|}{1940} & \multirow{2}{*}{ Age } & \multicolumn{2}{c|}{1957} \\
\cline { 2 - 5 } \cline { 5 - 8 } & Men & Women & & Men & Women & & Men & Women \\
\hline $0-20$ & 29.31 & 9.20 & $0-19$ & 20.14 & 57.35 & $18-24$ & - & 41.82 \\
\hline $21-40$ & 52.35 & 61.11 & $20-39$ & 45.87 & 37.03 & $25-39$ & - & 37.04 \\
\hline 41 and over & 18.05 & 29.61 & 40 and over & 33,99 & 5.62 & 40 and over & - & 21.15 \\
\hline Total=100 & 38.031 & 2.435 & Total=100 & 35.129 & 1.442 & Total=100 & - & 9.226 \\
\hline
\end{tabular}


Source: National Population Censuses, 1930-1940; Organización Sindical Española-

Servicio Sindical de Estadística, 1959, pp. 21-31.

Table 10. Labour force participation rates by women's marital status, 1930-1950

\begin{tabular}{|l|c|c|c|c|c|c|}
\hline \multirow{2}{*}{ Data } & \multicolumn{2}{|c|}{ Single women } & \multicolumn{2}{c|}{ Married women } & \multicolumn{2}{c|}{ Widows } \\
\cline { 2 - 7 } & $\mathbf{( 1 )}$ & $\mathbf{( 2 )}$ & $\mathbf{( 1 )}$ & $\mathbf{( 2 )}$ & $\mathbf{( 1 )}$ & $\mathbf{( 2 )}$ \\
\hline 1930 & 53.41 & 75.00 & 9.30 & 44.19 & 50.00 & 71.43 \\
\hline 1940 & 31.94 & 54.17 & 9.84 & 30.33 & 35.48 & 48.39 \\
\hline 1945 & 47.27 & 65.45 & 4.00 & 22.67 & 42.86 & 57.14 \\
\hline 1950 & 52.33 & 70.93 & 4.96 & 21.99 & 39.58 & 43.75 \\
\hline
\end{tabular}

(1) These rates are calculated based on the municipal censuses.

(2) These rates are calculated based on cross-checking the municipal census with the social security contribution records.

Source: Barcelona municipal censuses (1930-1950) and the social security contribution records (1925-1955).

Table 11. Labour force participation rates* by women's marital status and relationship to the head of household, 1930-1950

\begin{tabular}{|l|c|c|c|c|c|}
\hline Relationship & $\begin{array}{c}\text { Marital } \\
\text { Status }\end{array}$ & $\mathbf{1 9 3 0}$ & $\mathbf{1 9 4 0}$ & $\mathbf{1 9 4 5}$ & $\mathbf{1 9 5 0}$ \\
\hline Head of household & & 85.71 & 50.00 & 66.67 & 37.93 \\
\hline Spouse & & 45.00 & 26.97 & 14.29 & 17.92 \\
\hline \multirow{2}{*}{ Ascendant and collateral relatives } & Married & 33.33 & 12.50 & 50.00 & 0.00 \\
\cline { 2 - 6 } & Other & 61.54 & 50.00 & 55.56 & 61.11 \\
\hline $\begin{array}{l}\text { Daughters, daughters-in-law and other } \\
\text { descendant female relatives }\end{array}$ & Married & 52.63 & 52.63 & 50.00 & 57.89 \\
\cline { 2 - 6 } & Other & 74.36 & 50.00 & 70.21 & 66.22 \\
\hline
\end{tabular}

* These rates are calculated based on cross-checking the census data with the social security contribution records. 
Source: Barcelona municipal censuses (1930-1950) and the social security contribution records (1925-1955).

Table 12. Labour force participation rates* of married women by number of children under 15, 1930-1950

\begin{tabular}{|c|c|c|c|c|}
\hline No. children under 15 & $\mathbf{1 9 3 0}$ & $\mathbf{1 9 4 0}$ & $\mathbf{1 9 4 5}$ & $\mathbf{1 9 5 0}$ \\
\hline 0 & 50.00 & 53.85 & 33.33 & 28.57 \\
\hline 1 & 41.67 & 30.00 & 33.33 & 21.15 \\
\hline 2 & 40.00 & 26.32 & 12.50 & 22.73 \\
\hline 3 or more & 38.46 & 14.29 & 12.50 & 5.26 \\
\hline
\end{tabular}

* These rates are calculated based on cross-checking the census data with the social security contribution records.

Source: Barcelona municipal censuses (1930-1950) and the social security contribution records (1925-1955).

Table 13. Labour force participation rates* of married women by birth of each child and the intervening time, 1921-1955

\begin{tabular}{|l|c|c|c|}
\hline Child & Birth intervals (years) & $\mathbf{1 9 2 1 - 1 9 3 9}$ & $\mathbf{1 9 4 0 - 1 9 5 5}$ \\
\hline First child & & 44.63 & 44.44 \\
\hline \multirow{3}{*}{ Second child } & $<2$ & 42.31 & 0.00 \\
& $2+$ & 35.09 & 36.00 \\
\hline \multirow{3}{*}{ Third child } & Total & 36.90 & 28.13 \\
& $2+$ & 23.53 & 12.50 \\
\hline Fourth and subsequent & Total & 44.12 & 9.09 \\
children & & 36.54 & 10.00 \\
\hline
\end{tabular}

* These rates are calculated based on cross-checking the census data with the social security contribution records. 
The women have been viewed as employed if they had a job at the time of their children's births. If they did not have a job, the analysis has used the data on employment at the approximated beginning of their pregnancy.

Source: Barcelona municipal censuses (1930-1950) and the social security contribution records (1925-1955).

Table 14. Duration of leaves after childbirth, 1921-1955 (in \%)

\begin{tabular}{|l|c|c|}
\hline Length of leaves & $\mathbf{1 9 2 1 - 1 9 3 9}$ & $\mathbf{1 9 4 0 - 1 9 5 5}$ \\
\hline Shorter than 3 months & 58.77 & 43.33 \\
\hline Between 3 months and 5 years & 17.54 & 13.33 \\
\hline Longer than 5 years & 23.68 & 43.33 \\
\hline Total & $\mathbf{1 0 0}$ & $\mathbf{1 0 0}$ \\
\hline
\end{tabular}

Source: Barcelona municipal censuses (1930-1950) and the social security contribution records (1925-1955). 
Table 15. Family income strategies* in nuclear families, 1930-1950

\begin{tabular}{|c|c|c|c|c|c|}
\hline $\begin{array}{l}\text { Type of } \\
\text { nuclear } \\
\text { family }\end{array}$ & Strategy & 1930 & 1940 & 1945 & 1950 \\
\hline \multirow{5}{*}{ No children } & Husband works & 21.4 & 33.3 & 60.0 & 28.6 \\
\hline & Husband and wife work & 57.1 & 44.4 & 20.0 & 14.3 \\
\hline & Husband and wife work - they have/are lodgers & 0.0 & 11.1 & 20.0 & 28.6 \\
\hline & Husband works - they have/are lodgers & 21.4 & 11.1 & 0.0 & 28.6 \\
\hline & Total=100 & 14 & 9 & 5 & 7 \\
\hline \multirow{7}{*}{$\begin{array}{l}\text { Only with } \\
\text { children } \\
\text { under } 14 \\
\text { years of age }\end{array}$} & Wife works & 3.6 & 3.6 & 0.0 & 0.0 \\
\hline & Wife works - they have/are lodgers & 0.0 & 3.6 & 7.1 & 0.0 \\
\hline & Husband works & 53.6 & 82.1 & 50.0 & 56.5 \\
\hline & Husband and wife work & 28.6 & 7.1 & 7.1 & 4.3 \\
\hline & Husband and wife work - they have/are lodgers & 3.6 & 0.0 & 7.1 & 8.7 \\
\hline & Husband works - they have/are lodgers & 14.3 & 10.7 & 35.7 & 30.4 \\
\hline & Total=100 & 28 & 28 & 14 & 23 \\
\hline \multirow{12}{*}{$\begin{array}{l}\text { With } \\
\text { children } \\
\text { aged } 14 \text { and } \\
\text { over }\end{array}$} & Wife works & 0.0 & 5.0 & 0.0 & 2.9 \\
\hline & Wife and children work & 0.0 & 10.0 & 0.0 & 0.0 \\
\hline & Children work & 0.0 & 0.0 & 12.5 & 0.0 \\
\hline & Husband works & 14.3 & 40.0 & 25.0 & 28.6 \\
\hline & Husband and wife work & 0.0 & 0.0 & 6.3 & 2.9 \\
\hline & Husband, wife and children work & 71.4 & 10.0 & 6.3 & 11.4 \\
\hline & $\begin{array}{l}\text { Husband, wife and children work - they have/are } \\
\text { lodgers }\end{array}$ & 0.0 & 5.0 & 0.0 & 0.0 \\
\hline & Husband and wife work - they have/are lodgers & 0.0 & 0.0 & 0.0 & 5.7 \\
\hline & Husband and children work & 14.3 & 20.0 & 43.8 & 42.9 \\
\hline & Husband and children work - they have/are lodgers & 0.0 & 0.0 & 0.0 & 2.9 \\
\hline & Husband works - they have/are lodgers & 0.0 & 10.0 & 6.3 & 2.9 \\
\hline & Total=100 & 7 & 20 & 16 & 35 \\
\hline \multicolumn{2}{|c|}{ Total number of families } & 50 & 59 & 36 & 65 \\
\hline
\end{tabular}

* The data are calculated based on cross-checking the census data with the social security contribution records.

Source: Barcelona municipal censuses (1930-1950) and the social security contribution records (1925-1955). 
Table 16. Labour force participation rate* of married women by number of children and type of household, 1930-1950

\begin{tabular}{|l|l|c|c|c|c|}
\hline \multirow{2}{*}{$\begin{array}{l}\text { No. } \\
\text { children } \\
\text { under 14 }\end{array}$} & $\begin{array}{l}\text { No. } \\
\text { children } \\
\text { aged 14 or } \\
\text { over }\end{array}$ & $\begin{array}{c}\text { Simple } \\
\text { households }\end{array}$ & $\begin{array}{l}\text { Extended/multiple } \\
\text { family households }\end{array}$ & $\begin{array}{c}\text { Simple } \\
\text { households }\end{array}$ & $\begin{array}{c}\text { Extended/multipl } \\
\text { e family } \\
\text { households }\end{array}$ \\
\cline { 2 - 6 } & 0 & 57.14 & 40.00 & 42.86 & 42.70 \\
\hline 0 & 0 & 46.15 & 40.00 & 16.67 & 30.77 \\
\hline 2 or over & 0 & 25.00 & 55.56 & 9.09 & 26.67 \\
\hline $\begin{array}{l}\text { With children aged 14 } \\
\text { and over }\end{array}$ & 71.43 & 0.00 & 22.86 & 8.57 \\
\hline \multicolumn{2}{|l|}{ Total } & $\mathbf{4 6 . 0 0}$ & $\mathbf{4 1 . 6 7}$ & $\mathbf{2 1 . 5 4}$ & $\mathbf{2 2 . 0 8}$ \\
\hline
\end{tabular}

* The rates are calculated based on cross-checking the census data with the social security contribution records.

Source: Barcelona municipal censuses (1930-1950) and the social security contribution records (1925-1955). 


\section{Figures}

\section{Figure 1. The process from the sources to the calculation of the underreporting} and the activity rate (two individual examples).

1.a. The Social Security Records: The reconstruction of "Labour Lives"
\begin{tabular}{|c|l|c|c|}
\hline Personal Id. & \multicolumn{1}{|c|}{ Firm } & Entry & Exit \\
\hline $\mathbf{1 1}$ & Unknown situation without contribution & $01 / 05 / 1919$ & $31 / 10 / 1940$ \\
\hline $\mathbf{1 1}$ & Bertran, Gerardo Hijos de & $01 / 11 / 1940$ & $30 / 12 / 1941$ \\
\hline $\mathbf{1 1}$ & Unknown situation without contribution & $31 / 12 / 1941$ & $29 / 04 / 1952$ \\
\hline $\mathbf{1 1}$ & Riera, $A$ & $30 / 04 / 1952$ & $27 / 12 / 1960$ \\
\hline $\mathbf{1 1}$ & Unknown situation without contribution & $28 / 12 / 1960$ & $25 / 05 / 1978$ \\
\hline $\mathbf{1 1}$ & Retirement with contribution & $26 / 05 / 1978$ & $01 / 10 / 1994$ \\
\hline $\mathbf{2 7}$ & Unknown situation without contribution & $25 / 08 / 1929$ & $06 / 06 / 1944$ \\
\hline $\mathbf{2 7}$ & Concentración Industrias Metalúrgicas & $07 / 06 / 1944$ & $20 / 09 / 1944$ \\
\hline $\mathbf{2 7}$ & Unknown situation without contribution & $21 / 09 / 1944$ & $01 / 02 / 1946$ \\
\hline $\mathbf{2 7}$ & Mariin Martinez, Jose & $02 / 02 / 1946$ & $02 / 05 / 1946$ \\
\hline $\mathbf{2 7}$ & Unknown situation without contribution & $03 / 05 / 1946$ & $05 / 05 / 1946$ \\
\hline $\mathbf{2 7}$ & Manufacturas de Artículos de Viajes Bayer SA & $06 / 05 / 1946$ & $08 / 07 / 1946$ \\
\hline $\mathbf{2 7}$ & Unknown situation without contribution & $09 / 07 / 1946$ & $14 / 07 / 1946$ \\
\hline $\mathbf{2 7}$ & Bertran, Gerardo Hijos de & $15 / 07 / 1946$ & $30 / 09 / 1947$ \\
\hline $\mathbf{2 7}$ & Unknown situation without contribution & $01 / 10 / 1947$ & $16 / 01 / 1948$ \\
\hline $\mathbf{2 7}$ & Sobriza Freixenet SA & $17 / 01 / 1948$ & $01 / 01 / 1950$ \\
\hline $\mathbf{2 7}$ & Unknown situation without contribution & $02 / 01 / 1950$ & $08 / 02 / 1959$ \\
\hline $\mathbf{2 7}$ & Mullor SA & $09 / 02 / 1959$ & $12 / 01 / 1969$ \\
\hline $\mathbf{2 7}$ & Unknown situation without contribution & $13 / 01 / 1969$ & $31 / 01 / 1975$ \\
\hline $\mathbf{2 7}$ & Retirement with contribution & $01 / 02 / 1975$ & $31 / 12 / 2004$ \\
\hline & & & \\
\hline
\end{tabular}

1.b. The Municipal Censuses: Labour declaration

\begin{tabular}{|c|c|l|}
\hline Personal Id. & Census Data & Census Declaration \\
\hline $\mathbf{1 1}$ & $31 / 12 / 1930$ & School \\
\hline $\mathbf{1 1}$ & $31 / 12 / 1940$ & No information \\
\hline $\mathbf{1 1}$ & $31 / 12 / 1945$ & Homecaring \\
\hline $\mathbf{1 1}$ & $31 / 12 / 1950$ & Graphic arts \\
\hline $\mathbf{2 7}$ & $31 / 12 / 1930$ & No information \\
\hline $\mathbf{2 7}$ & $31 / 12 / 1940$ & No school \\
\hline $\mathbf{2 7}$ & $31 / 12 / 1945$ & Apprentice \\
\hline $\mathbf{2 7}$ & $31 / 12 / 1950$ & Homecaring \\
\hline
\end{tabular}

The result of the Cross-checking of the sources

1.c. The labour position in a concrete data

\begin{tabular}{|c|c|l|l|l|}
\hline \multirow{2}{*}{ Personal Id. } & \multirow{2}{*}{ Data } & \multicolumn{3}{|c|}{ Labour Position } \\
\cline { 3 - 5 } & & \multicolumn{1}{|c|}{ Census } & sS Records & \multicolumn{1}{c|}{ Corrected } \\
\hline $\mathbf{1 1}$ & $31 / 12 / 1930$ & Not working & Not working & Not working \\
\hline $\mathbf{1 1}$ & $31 / 12 / 1940$ & Not working & Working & Working \\
\hline $\mathbf{1 1}$ & $31 / 12 / 1945$ & No working & Not working & Not working \\
\hline $\mathbf{1 1}$ & $31 / 12 / 1950$ & Working & Not working & Working \\
\hline $\mathbf{2 7}$ & $31 / 12 / 1930$ & Not working & Not working & Not working \\
\hline $\mathbf{2 7}$ & $31 / 12 / 1940$ & Not working & Not working & Not working \\
\hline $\mathbf{2 7}$ & $31 / 12 / 1945$ & Working & Not working & Working \\
\hline $\mathbf{2 7}$ & $31 / 12 / 1950$ & Not working & Working & Working \\
\hline
\end{tabular}

1.d. The number of women working in a concrete data

\begin{tabular}{|c|c|c|c|c|}
\hline \multirow{2}{*}{ Data } & \multicolumn{3}{|c|}{ Women Working } & \multirow{2}{*}{ Total Women } \\
\cline { 2 - 4 } & Census & SS Records & Corrected & \\
\hline $\mathbf{3 1 / 1 2 / 1 9 3 0}$ & 0 & 0 & 0 & 2 \\
\hline $\mathbf{3 1 / 1 2 / 1 9 4 0}$ & 0 & 1 & 1 & 2 \\
\hline $\mathbf{3 1 / 1 2 / 1 9 4 5}$ & 1 & 0 & 1 & 2 \\
\hline $\mathbf{3 1 / 1 2 / 1 9 5 0}$ & 1 & 1 & 2 & 2 \\
\hline
\end{tabular}

$$
\checkmark
$$

1.e. The calculation of the under-reporting and the activity rate

\begin{tabular}{|c|c|c|c|c|}
\hline \multirow{2}{*}{ Data } & \multirow{2}{*}{ Census underreporting } & \multicolumn{3}{|c|}{ Activity Rate } \\
\cline { 3 - 5 } & & Census & SS Records & Corrected \\
\hline $\mathbf{3 1 / 1 2 / 1 9 3 0}$ & - & $0 \%$ & $0 \%$ & $0 \%$ \\
\hline $\mathbf{3 1 / 1 2 / 1 9 4 0}$ & $100 \%$ & $50 \%$ & $50 \%$ & $50 \%$ \\
\hline $\mathbf{3 1 / 1 2 / 1 9 4 5}$ & $0 \%$ & $50 \%$ & $50 \%$ & $50 \%$ \\
\hline $\mathbf{3 1 / 1 2 / 1 9 5 0}$ & 50 & $100 \%$ & $100 \%$ & $100 \%$ \\
\hline
\end{tabular}


Source: Barcelona municipal censuses (1930-1950) and the social security contribution records (1925-1955).

Figure 2. Women's labour force participation rate by age, 1925-1955

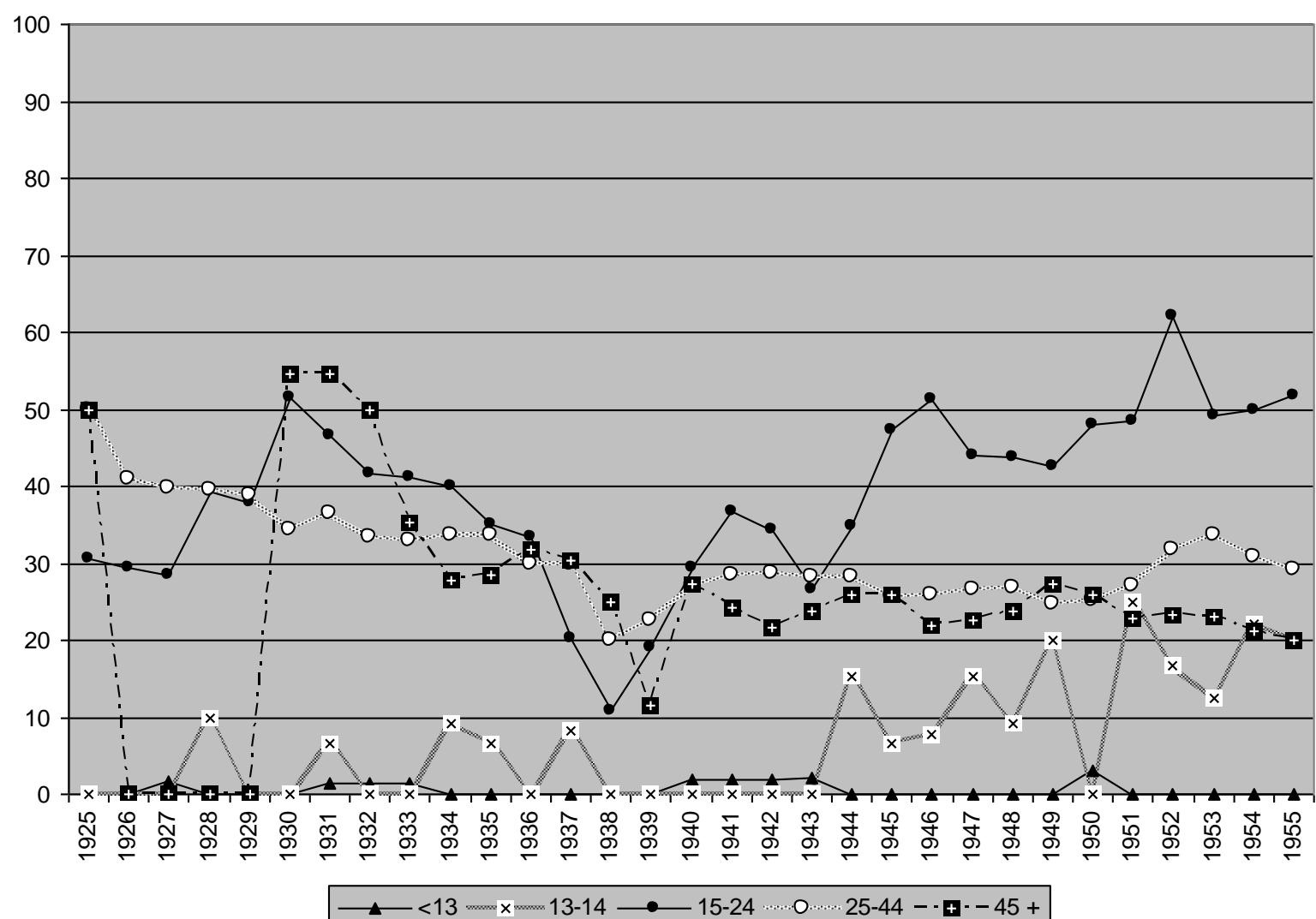

The position in the regulated labour market (working/not working) has been observed at 31 December of each year.

Source: Social security contribution records (1925-1955). 